\title{
Homer in Goethe's Iphigenie auf Tauris and in Grillparzer's Weh dem, der lügt!
}

\section{Hansgerd Delbrück}

One of the most striking links with Homer identified by John Davidson $^{2}$ in Euripides' tragedies also features in Goethe's Iphigenie auf Tauris: the scar which in Euripides' Electra reveals Orestes' identity to Electra, and in the Odyssey reveals Odysseus' identity to his wet-nurse, Eurycleia. However, Goethe presents this motif with a twist. In his play, based on Euripides' Iphigenia in Tauris, no such outward marker is needed for Orest and Iphigenie to discover each other's identity: Orest discloses his name to Iphigenie because he perceives her to be a "great soul" (große Seele) whom he cannot bear to deceive, and she then tells him who she is to relieve the pain he feels from being persecuted by the Furies. It is only later, when Thoas, the king of the Taurians, asks for proof of her claim that Orest is her brother, that she points to the scar running through his eyebrow ever since Electra let him fall from her arms as a child (lines 2087-88). ${ }^{3}$ Of course, by that stage it is too late for Orest's identity to make any difference to Thoas, who feels deeply betrayed by the Greeks: accusing Orest of being one of those Greeks determined from time immemorial to rob the barbarians of their treasures, he challenges Orest to fight. Orest, under the influence of Iphigenie's idealistic humanity, responds to this challenge by offering to surrender the cult statue of Diana

\footnotetext{
1 The title of Goethe's play and the names of its characters will be given throughout in the original German to avoid confusion with Euripides' tragedy. For consistency, Grillparzer's play will also be referred to by its German title, Weh dem, der lügt! Its English translation is "Woe to him who lies!" The German editions referred to are: Iphigenie auf Tauris in Johann Wolfgang Goethe, Dramen 1776-1790, ed. Dieter Borchmeyer (Frankfurt am Main: Deutscher Klassiker Verlag, 1988), 553-619 and Weh dem, der lügt! in Franz Grillparzer, Dramen 1828-1851, ed. Helmut Bachmaier (Frankfurt am Main: Deutscher Klassiker Verlag, 1987), 195-273. English translations from these plays are mine.

2 See the first essay in this collection: John Davidson, "Euripides and Homer," 16-17.

3 Some lines earlier, Iphigenie points to the birthmark on Orest's right hand (lines 2082-86).
} 
which he had stolen from the temple. But Thoas remains deeply disgruntled and disappointed, and while he feels that he can no longer prevent the Greeks from returning to their country, he sends them away with curt and unloving words. Only after Iphigenie asks him for a kind and auspicious farewell does he soften: his final words "Fare well" show his change of heart.

In Euripides' own Iphigenia in Tauris, the means of identification are more sophisticated than in Electra, as Euripides makes a letter by Iphigenia the means by which her identity is revealed to Orestes, who then reveals his own identity to her. But Goethe's use of anagnorisis is categorically different from that play as well: while intrigued by the complexity of Iphigenia's and Orestes' characters in Iphigenia in Tauris, he felt that Euripides had denied them psychological development. In his own play the mutual recognition between brother and sister prevents the family curse of the House of Atreus from coming to its climax, which would have been Iphigenie's ritual sacrifice of her own brother Orest, but the sacrifice in fact happens in Orest's imagination, resulting in his final curing "through a psychological process of transformation, amounting in effect to a symbolic death and rebirth" (79). ${ }^{4}$ Of course, Goethe's protagonist is Iphigenie rather than Orest: while the recognition between brother and sister culminates in act 3 in Orest's cure from the mental torment from which he has been suffering as the murderer of his mother Klytemnestra, in acts 4 and 5 it is Iphigenie who suffers in her soul a turmoil of her own as she tries to secure their escape from the land of the Taurians in a way that is consistent with her idealistic view of humanity. Like Orest, she overcomes this turmoil by a psychological transformation, but, unlike Orest's, Iphigenie's transformation appears to have been suggested to Goethe by Euripides' Iphigenia at Aulis: in that play, the discrepancy between, on the one hand, Iphigenia's desperation at her

4 Cyrus Hamlin, "Myth and Psychology': The curing of Orest in Goethe's Iphigenie auf Tauris," Goethe Yearbook 12 (2004): 79. Cf. Hartmut Reinhardt, "Die Geschwister und der König: Zur Psychologie der Figurenkonstellation in Goethes Iphigenie auf Tauris," in Deutsch-italienische Studien, ed. Roberto Cottieri (Merano, 2000), 180: "Die 'heilende Berührung' ist für jenes quasi psychotherapeutische Gespräch zu substituieren, in dem Iphigenie den Muttermörder dazu bringt, eine Schuldfixierung im Aussprechen 'durchzuarbeiten." 
impending death and, on the other, her willing acceptance of it as a sacrifice to Artemis, implicitly suggests a similar psychological transformation. ${ }^{5}$ However, the human sacrifice practised by the Greeks in Iphigenia at Aulis makes it obvious that civilisation and barbarity are not fixed entities, but variables that depend on the actual level of moral development: by accepting of her own free will to become the victim of human sacrifice, the protagonist opts for a practice which in the eye of a modern audience is barbaric. Moreover, in Iphigenia at Aulis the protagonist states only once that she will be sacrificed to Artemis, whereas she stresses four times that she will be sacrificed for Greece. ${ }^{6}$ By contrast, in Goethe's own play the development of Iphigenie's character to a higher level of humanity is based less on politics than on religion, namely on Iphigenie's faith in the Olympian Gods. Thus, Goethe's implicit criticism of Iphigenia in Tauris suggests that, at a deeper level, Euripides' concept of religion did not resonate with him either. In both Iphigenia in Tauris and Iphigenia at Aulis the gods are so far removed from the world of men that access to them appears heavily constrained, resulting in a sense of powerlessness to influence one's own fate. For the same reason, Goethe appears to have felt something missing in Euripides' development of the plot in Iphigenia in Tauris (where Athena's intervention is restricted to the theatrical device of dea ex machina at the end of the play).

Surprisingly, Goethe appears to have used Homer as the basis and backdrop of his revision of Iphigenia in Tauris and Iphigenia at Aulis to present his own concept of humanity based on religion, with a particular emphasis on openness and truth. The first part of this essay will demonstrate this by examining the resonances from Iphigenia at Aulis in Orest's and Iphigenies's recognition of Diana /Artemis, and the resonances from Homer's epics in the development of Iphigenie's complex character and in her attempt to harmonise in her soul the image of two goddesses, Athena and Artemis. The second part of the essay will argue that a critical response to Goethe's own play can be detected in the way in which the Austrian playwright Franz Grillparzer employs numerous

5 Uwe Neumann, Gegenwart und mythische Vergangenheit bei Euripides (Stuttgart: Franz Steiner Verlag, 1995), 100.

${ }^{6}$ Ibid., 100 n. 14. 
allusions to Euripides as well as Homer in his comedy Weh dem, der lügt! That part of the essay will focus on Grillparzer's rejection of Goethe's psychological, introspective concept of religion, and on his parody of Goethe's exaggerated idealism. The essay will conclude with a discussion of the fairness of Grillparzer's parody.

Goethe was far from simply wanting to replace Athena's personal intervention in Euripides' play with a human solution to Iphigenia's, Orestes' and Thoas' problems: the protagonists of his own play are deeply devoted to the religion of the Olympian Gods. However, Goethe has the gods appear in men's souls rather than in person: their appearance leaves the soul with an imprint of their image which becomes visible ${ }^{7}$ through that individual, by changing his or her outlook on life as well as that of other human beings. This can be seen in the way in which Goethe treats Diana's influence on Iphigenie and Orest. Iphigenie's recognition of Diana as the goddess who saved her from violent death on the altar at Aulis, has left the image of her saviour as a merciful goddess ingrained in her soul, and instilled in her, Diana's priestess, feelings of pity and humanity towards any shipwrecked men coming to Tauris, whether Greeks or Barbarians, and indeed towards anybody struck by misery (lines 1841-53). This is the source of her humane idealism in the play. For Orest's disturbed and suffering mind to begin to heal, ${ }^{8}$ it is in turn sufficient for him to be exposed to the environment of Diana's sacred grove and to her aura in the words and actions of Iphigenie, her priestess: there is no need for any contact with Diana's statue (Götterbild) kept in

7 The gods become audible as well as visible to those who open their souls to them: "the voice of truth (or truthfulness) and humanity" (die Stimme / der Wahrheit und der Menschlichkeit, lines 1937-38). This also applies to the Gods of the Underworld: in the last scene of act 2, when Orest awakens from his madness, he hears the Eumenides leave and close the doors of Tartarus behind them (lines 1359-61).

${ }^{8}$ The cure is completed once Iphigenie discloses her identity to her brother. See Hamlin (n. 4 above): 63: "The cure of the curse symbolized by the Furies who pursue him is achieved through this reciprocal verbal act of recognition. [...] It is a psychoanalytic cure through the recounting in dialogue of a shared mythical history of reciprocal identity." 
her temple, let alone with the goddess herself, except in his own soul. At the end of the play he finds it correspondingly easy to surrender the statue, once he finally understands that the oracle which had stipulated that he should bring the image of "the sister" from the land of the Taurians back to Greece was in fact referring to his own sister, Iphigenie, rather than to Apollo's sister, Diana (lines 2107-15). The concept of human beings as "images of the gods" (Götterbilder) is pervasive in Goethe's play, although not always under the same label: Iphigenie herself, at the beginning of act 2, reacts to Pylades' news of the death of many Greek heroes in the Trojan war, including Achilles, by referring to them as such: "And so you images of gods are turned to dust as well" (line 864). This is a variant of the term "great soul" (line 1076), used by Orest to refer to Iphigenie in the scene of recognition between brother and sister, or "noble soul" (line 2143), used by Iphigenie to describe Orest in her attempt to persuade Thoas to allow the Greeks to return to their fatherland. At the beginning of the play, Thoas himself is called a "great soul" (line 181) by Arkas as he attempts to persuade Iphigenie to assent to Thoas' marriage proposal, while at the end of the play the barbarian king demonstrates the greatness of his soul by resigning himself to her rejection of his marriage proposal and to her return home. Ultimately, both terms ("image of the gods" and "great [or noble]

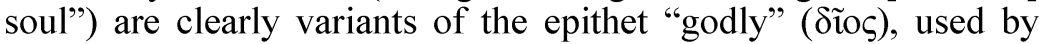
Homer of gods as well as great heroes such as Achilles and Odysseus." Another variant is the word "like one from Heaven" (line 951) used by Orest as an epithet for Iphigenie at the beginning of the play, after she has spoken her first words to him and relieved him from his prisoner's chains. In line 1127 he simply addresses her as "you heavenly one." (At this stage of the play he does not yet know that she is, specifically, an image of the goddess Diana.)

Earlier in the play, Iphigenie and Orest had believed that they needed to hatch a plan to escape from the Taurians, taking the statue of Diana with them. Goethe's view appears to have been that Euripides blemished the character of Iphigenia unnecessarily by letting her construct an escape plan involving deceit, and so Goethe makes Pylades responsible for the deceit, and it is Iphigenie's

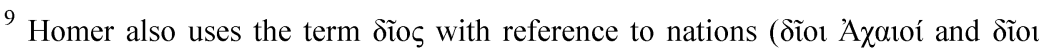

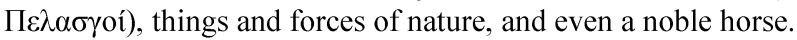


reluctance to go along with it that makes her turn to the "Olympians" for help. She asks them to grant her two prayers which in her mind are interconnected: to save her, and to save her from losing faith in the Olympian Gods: "Save me / and save your image in my soul!" (lines 1716-17). The words of these two lines, with the emphasis on the second line, are crucial to our understanding of the "Greek" theology implicit in Goethe's dramaturgy: according to Iphigenie, only with the help of the gods can human beings live and act in their image, and also see the gods at work in the souls and actions of their fellow men. In particular, if men are at risk of losing their (internalised) images of the gods (which is Iphigenie's term for losing faith in the goodness of the gods), they need help from the gods themselves, ${ }^{10}$ rather than from any image of them, be it a cult statue or a preconceived image in the soul. Hamlin rightly states that "the reciprocal verbal act of recognition" between Iphigenie and Orest which culminates in the cure from his madness "constitutes the central tragic action of Goethe's drama," "but the central non-tragic action of the drama is Iphigenie's interaction with the gods, which then impacts on the resolution of her conflict with Orest, Pylades and Thoas.

\footnotetext{
${ }^{10}$ Wolfdietrich Rasch, Goethe's Iphigenie auf Tauris als Drama der Autonomie (München: C.H. Beck, 1979), 147 and 164, states that Iphigenie's call upon the gods to save their image in her soul is no prayer, but a demand that amounts to a challenge of the gods without challenging the existence of the gods. But why should a prayer that contains a desperate demand not be called a prayer? Kevin Lee, "Goethe's Iphigenie and Euripides' Iphigenia in Tauris," AUMLA, special issue (February 2003): 74, shows a complete disregard for the religious side of Goethe's Iphigenie auf Tauris, effectively making Thoas the central figure of Goethe's play and presenting the king's final farewell to Iphigenia and the Greeks as "the muted tones of an ending controlled by human, ultimately disappointed hands." According to Heinz Gockel, "Iphigenie und der Mythos," in Heinz Gockel, Literaturgeschichte als Geistesgeschichte: Vorträge und Aufsätze (Würzburg: Königshausen und Neumann, 2005), 75, Iphigenie is, ultimately, fabricating the gods in her soul: "Iphigenie setzt auf das Bild der gütigen Götter. Mehr noch, sie verlagert die Götterwelt in das Innere des Menschen. Das heißt in der Konsequenz: es gibt keine anderen Götter als die, die der Mensch sich macht." This statement seems to go too far: one wonders whether Goethe himself at any stage of his life meant to present religion as a human fabrication.

${ }^{11}$ Hamlin (n. 4 above): 63.
} 
But which god will help Iphigenie? While Goethe did not adopt Euripides' device of dea ex machina, he appears to have had no problems with Athena coming to Iphigenie's rescue, rather than Artemis. After all, Euripides had prepared for Athena's appearance in Iphigenia's prayer to Artemis, which ends in a plea for forgiveness for using deceit to secure the fugitives' return to Greece: it is Athena rather than Artemis who is connected to qualities of the mind, including honesty and truth. However, the problem which makes Goethe's Iphigenie turn to the Olympians for help is not the same as the problem solved by Euripides' dea ex machina. In Euripides' play, the problem is largely physical: a powerful wave pushes the fugitives' ship back towards the shores of the Taurians, delivering the Greeks to Thoas, and Athena has to make the wind turn in the right direction to bring the ship back on course to Greece. She then simply orders Thoas to let the Greeks leave his shores. In Goethe's play, Iphigenie's problem is psychological: it is the wrath of Thoas rather than the waves of the sea which needs to be calmed.

Since, in Thoas' view, Iphigenie, by her refusal of his marriage proposal and her decision to leave him and his country, has abandoned the very humanity that had attracted him to her, any attempt of hers to quench his wrath by appealing to his humanity would seem of necessity doomed to failure and only to increase his resentment. Read with Homer in mind, the emotionally draining dialogue in which she eventually succeeds in convincing him to grant her her freedom, while never giving up her idealistic belief in humanity and truthfulness, reveals a spectacular development of her character, through the influence of the goddess Athena. Iphigenie begins with a woman's usual plea for peace, but by the end is able to muster as much fighting spirit and courage as a man wielding his weapons of iron. In her new-found courage she recalls the second book of the Iliad, where Odysseus, in a similar mood of despondency, is given the courage by Athena to spur his fellow warriors on to the fight against the Trojans. It is as if the Olympians had responded to Iphigenie's prayer by imprinting in her soul the image of the Warrior Goddess, Athena. Just like Odysseus in the Iliad, she shows her courage using no other weapons than words. And just as Diana's impact on Orest's soul 
was only visible in the way in which his mind was healed by Iphigenie, the image of Athena forming in Iphigenie's soul shows only in its impact on her words and actions, as she gradually builds up the courage she needs to counteract Pylades' deception by revealing it to Thoas.

How does this happen? In act 5, scene 3 , Iphigenie, increasingly agitated, warns Thoas that in warfare the mighty must beware the deceit and artifice of the weak. When Thoas simply responds that a cautious man will not be deceived, she suddenly grasps with utmost clarity what so far had only reached her mind and soul in a vague sense of unease: Pylades' deceitful plan is not so much Thoas' problem as her own. If she were to use the weapons of deceit and artifice against him-the weapons often used in Homer's epics not only by Odysseus the Cunning, but also by his protective goddess, Athena ${ }^{12}-$ she would not only put an unacceptable blemish on her return home to Greece by hurting Thoas, but also thereby cause her image of Athena (as a deceitful goddess) to clash with that of Diana (as a humane, merciful goddess). In this utter predicament, apparently without a way out, she wonders whether she should call to "the goddess" for a "miracle," adding the question whether she herself has no powers in the depths of her soul (lines 1884-85). ${ }^{13}$ These two questions, put at that moment, not only remind us of the two lines of her previous prayer to the Olympians, but also confirm that the goddess she is referring to must be Athena, as it is Athena's rather than Diana's image that needs to be saved in her soul. Consequently, in contrast to Euripides' play, the miracle that is the answer to her prayer is performed by Athena re-entering Iphigenie's soul with a different face. This face is revealed by Iphigenie's own actions, as she suddenly dares to confront Thoas with the truth about the deceit with which her and the Greeks' departure had been planned. The openness and truth with which

\footnotetext{
${ }^{12}$ For example, in the Iliad Athena uses deceit to lure Hector to his fatal combat with Achilles.

13 According to Karina Becker, Autonomie und Humanität: Grenzen der Aufklärung in Goethes Iphigenie, Kleists Penthesilea und Grillparzers Medea (Frankfurt am Main: Peter Lang, 2008), 37, Iphigenie's answer to her questions in lines $1884-85$ is not to ask the goddess for a miracle, but to put her hope into the depths of her soul. However, there is no reason why Iphigenie cannot ask the goddess for a miracle as well as put her hope into the depths of her soul.
} 
she finally wins over Thoas reminds us not only of Orest's previous emphatic decision to reveal his identity to his sister, ${ }^{14}$ but also of Athena's advice to Telemachus in book 2 of the Odyssey, to kill his mother's suitors "either by trickery or openly." Overall, however, in Goethe's play the formation of Iphigenie's character appears to have been inspired most strongly (though not exclusively ${ }^{15}$ ) by book 1 of the Odyssey. Athena's speech to Telemachus, intended by the goddess to make Odysseus' son into a man, is so successful that both his mother Penelope and the assembly of her suitors are impressed by his new-found authority. This striking success of Athena's attempt to educate Telemachus is due not only to the inspirational words of the goddess, but also to what one might call Homer's developmental psychology: he presents Telemachus at that specific stage of adolescence in which he not only longs to become a man, but is ready for it. Similarly, in Goethe's play Iphigenie "grows" into the woman she becomes (with an authority over men different from the one she had when Thoas approached her with his marriage proposal and Orest addressed her as a "heavenly one"), from a woman who appears to have this new development of her features already dormant in her soul, ready to be awakened into reality: in the first scene of the play, she broods over the fact that, while she does not want to argue with the gods, she does find the position of women deplorable as compared with that of men (lines 23-24). Even Iphigenie's use of the word "soul" to describe what is going on inside her appears to be indebted to Goethe's knowledge of a range of similar words in book 1 of the Odyssey, translated by Voss with im innersten Herzen ("deep in his heart"), Seele ("soul") or Herz

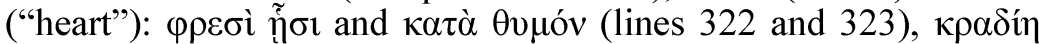

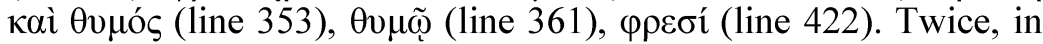
lines 322-23 and 422, the word $\varphi \rho \varepsilon \sigma i$ is used by Homer when Telemachus suddenly recognises in his heart (or soul) that he has been visited by Athena disguised as Mentes. ${ }^{16}$

\footnotetext{
14 Lines 1080-81 contain one of the most often quoted sentences of the play: "zwischen uns / sei Wahrheit!"

15 For implicit psychological development in Iphigenia at Aulis see the introduction to this essay.

${ }^{16}$ While in the Iliad the Olympians usually visit men undisguised, in the Odyssey this only happens once: at the beginning of book 15, when Athena visits Telemachus as herself. Shirley Darcus Sullivan, Euripides' Use of Psychological
} 
There are, of course, differences between the fighting spirit which Athena wants Telemachus to develop and that which she encourages in Iphigenie, and these differences go beyond those to be expected between a young man and a young woman. As befits the son of a war hero, Telemachus is to develop the ambition of one day matching his father's fame and glory as the scourge of his enemies. For the time being, his only enemies are the enemies of his father, his mother's suitors: in this respect he is in a loosely similar position to Orestes when he avenged his father Agamemnon by killing his mother's lover Aegisthus. Therefore Athena reminds Telemachus of the glory that Orestes won by killing Aegisthus (1.298). ${ }^{17}$ Telemachus' ambition to become a great warrior is obviously at odds with Iphigenie's peaceful concept of humanity, obtained from Diana, which it is her ambition to apply to men as well as women. But her recognition of truthfulness as the other side of the Goddess of Wisdom explains her sudden ability to overcome the devastating clash between the images of Athena and Diana in her own soul. With the image of Athena as Goddess of Wisdom saved in her soul, Iphigenie is henceforth protected by both Athena the Warrior Goddess and Athena the Goddess of Wisdom, no less than Odysseus and Telemachus. $^{18}$

Yet, in contrast to Odysseus and Telemachus, Iphigenie is also protected by a third feature of her complex character which she shares with Athena from the beginning of the play, even before she turns to the gods for help. Unlike in Euripides' Iphigenia in Tauris,

Terminology (Montreal, London, Ithaca: McGill-Queen's University Press, 2000), 120, points out that Euripides, too, mentions $\varphi \rho \eta ์ v$ or, in the plural, $\varphi \rho \varepsilon ́ v \varepsilon \zeta$ "most often of the psychic entities (160 times). [...] First, phren is associated with deliberation, pondering, and consideration of possibilities of action. Second, phrenes are the means that people resort to in times of crisis. At such times they must ponder and reflect." However, in Euripides' plays there appears to be no

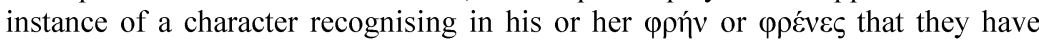
been visited by a god.

${ }^{17}$ While at the beginning of book 1 of the Odyssey, in the assembly of the gods, Zeus mentions that Orestes killed Aegisthus to avenge his father, the Odyssey does not contain any reference to Orestes' murder of his mother.

${ }^{18}$ It goes without saying that Iphigenie is not meant to have any knowledge of the content of the Odyssey. Rather, Goethe has made his protagonist experience a variation of Athena's epiphany to Telemachus. 
in Goethe's play Thoas is confronted not only with Iphigenie's wish to return to Greece, but also with her refusal to accept his marriage proposal. This makes it all the more difficult for her to win his agreement to her departure. Yet her refusal is not, as suggested in Kindler's Literatur Lexikon, ${ }^{19}$ the obstinacy of an obdurate child. On the contrary, her desire to remain unmarried is in keeping with the virginity of her protective goddess, Athena Parthenos (as well as the other Virgin Goddess, Diana, lines 198200). Without this ever being made explicit in the play, it can be seen as the reason why Thoas in the end resigns himself not only to Iphigenie's departure, but also to the loss of her as his future wife.

In total, Iphigenie's complex character, ultimately defined by her relationship to the gods, has four features which have come to her from the two goddesses Diana and Athena: humanity, fighting spirit, truthfulness, and virginity. This reminds us of the depiction of Agamemnon (in Iliad 2.478-79) as a ruler who in four different parts of his body (eyes, head, waist and chest) resembles three different gods: Zeus, Ares and Poseidon. Since in the Iliad the equation of outward and inner beauty (and ugliness, see Odysseus' treatment of Thersites) is taken for granted, those four parts of Agamemnon's body capture the specific strength of his inner character, his authority as ruler and supreme leader over his troops. In the Iliad the ensemble of Agamemnon's godly limbs, aggregated from different gods, represents the complex character of a supreme leader already fully developed. In Goethe's play, Iphigenie's ability to make her return to Greece concur with her "beautiful image of her journey home" (der Rückkehr schönes Bild) ${ }^{20}$ depends on her saving in her soul the [beauty of] the images of Diana and Athena. As long as they are both beautiful, they will not clash with each other, but ensure the beauty and harmony of Iphigenie's own character.

In his reading of Homer's Odyssey Goethe may well have felt encouraged by an important difference between the Odyssey and the Iliad that more recently has been highlighted by Wolfgang

\footnotetext{
19 Gisela Hesse, "Iphigenie auf Tauris. Schauspiel von Johann Wolfgang von Goethe," Kindlers Literatur Lexikon, vol. 5 (Zürich: Kindler, 1970), 4875.

${ }^{20}$ In line 1891 Thoas refers to Iphigenie's "beautiful image of [her] journey home" in a derogatory, ironic sense, to depict her departure as an injustice to him and the Taurians.
} 
Kullmann. ${ }^{21}$ In the Iliad, for their own reasons and without any regard for natural justice, the Olympian Gods bring tragedy to men. By contrast, in the Odyssey they are generally seen as fair guarantors of justice. ${ }^{22}$ Kullmann points out that this difference between the Odyssey and the Iliad cannot be explained by the passage of time, as there are elements of the portrayal of the gods prevalent in the Odyssey in the Iliad, and vice versa. In Goethe's play, the simultaneity of conflicting moral ideals, augmented by the ideal of humanity through openness and truth, is reflected in the interrelationship between the Olympian Gods, with ideals conflicting even within individual gods. Goethe's Iphigenie conceives of the solution to this conflict as moral progress towards humanity. ${ }^{23}$ While in Goethe's play no Olympians make their appearance outside the hearts and minds of the protagonists, Telemachus' retrospective recognition of Athena in book 1 of the Odyssey is mirrored in Iphigenie's recognition upon her arrival in Tauris that her image at Aulis of Diana as a cruel goddess had been wrong. ${ }^{24}$ It is also mirrored in Orest's recognition of the true

21 Wolfgang Kullmann, Homerische Motive: Beiträge zur Entstehung, Eigenart und Wirkung von Ilias und Odyssee (Stuttgart: Steiner, 1992), 288-89.

${ }^{22}$ In particular, Kullmann refers to the father of Odysseus, Laertes, who in book 24 takes the news of the punishment of the suitors as proof of the existence of the gods.

23 In her dialogue with Thoas in act 5, lines 1916-19, calling upon the gods one last time, Iphigenie demands that they demonstrate their truthfulness by glorifying truth through her. At that stage, of course, she is not perturbed by conflicting images in her soul of Diana and Athena, but by conflicting signals received from the two Gods of Truth, Athena and Apollo: his demand that Orest should bring the statue of "the sister" from Tauris to Greece had resulted in Pylades' plan to remove the statue of Diana from the temple of Tauris by deceit, as Thoas was never going to accept the removal of the statue. According to Denise Blondeau, "Die Konstitution des Subjekts in Goethes Iphigenie auf Tauris," Actes du colloque interdisciplinaire tenu à l'Université de Reims Champagne-Ardenne (Reims, Octobre 1997), (Bonn: Romanistischer Verlag, 2000), 105, in that dialogue Iphigenie does not pray to the gods, but addresses "men in general" (die Männer) as well as, for the time being (vorerst), Thoas and, while absent, Orest, Arkas and Pylades. This makes little sense, as Iphigenie is determined to reveal the truth to Thoas at that very moment.

24 In her report of her rescue from Aulis, Iphigenie has no recollection of a personal appearance of the goddess; when lying on the altar she was so frightened 
meaning of the oracle used by Apollo to send him to the land of the Taurians. Both these retrospective recognitions point to a change of heart in Diana and Apollo themselves, from cruelty towards humanity. ${ }^{25}$

However, Goethe has balanced this idealistic view of the Olympian Gods by giving the impact of the Furies or Eumenides (or Erinyes as they are called by Homer, mostly in the singular) a much stronger presence in his play than they have in Homer's epics and in Euripides' Iphigenia in Tauris: while the Goddesses of the Underworld are "foreign bodies" 26 in a play dominated by the Olympian Gods, as instigators of Orest's insanity they are brought into the play in his highly dramatic recollection to Iphigenie of how they had attacked him after he had murdered his mother (lines 1052-70). Similarly, after asking the gods to save their image in her soul, Iphigenie gives voice to her desperation by singing the Song of the Fates (Lied der Parzen), in which the cruelty of the Olympians against the Titans is cited at length to picture their cruelty against humankind; although this song is referring back to a distant past, it is meant to capture her present despair. And Orest's claim at the end of the play, when he realises his earlier mistaken interpretation of the Oracle, that "a god had put falsity like a veil around our heads" (lines 2108-09) refers to a past that is not all distant.

Nevertheless, many readers have felt somewhat uncomfortable with Goethe's promotion of humanism through truth in Iphigenie auf Tauris. Notably Theodor W. Adorno, with due respect for the modernity $^{27}$ of the play, went so far as to state that the final

that she fainted, emerging from her swoon only after her arrival in Tauris (lines 1846-51).

${ }^{25}$ While the Odyssey does not contain any reference to Orestes' murder of his mother, Goethe's Iphigenie is unaware of the fact that Athena's concept of justice, as shown at the end of the Odyssey, allows for the cruel killing of trespassers.

${ }^{26}$ Ulrich Port, "Goethe und die Eumeniden: Vom Umgang mit mythologischen Fremdkörpern," Jahrbuch der deutschen Schillergesellschaft 49 (2005): 153-98.

27 See also Annette Simonis, "Intertextualität und Intermedialität als Chance? Zur Adaption mythologischer Figuren im Drama um 1800 am Beispiel von Mozarts Idomeneo und Goethes Iphigenie auf Tauris," in Zukunft der Literatur, Literatur der Zukunft, ed. Reto Sorg, Adrian Mettauer and Wolfgang Pross (München: 
reconciliation between Thoas and Iphigenie is obtained "surreptitiously", 28 which comes close to accusing Goethe of fraudulence. However, noting almost apologetically that at the time of the Bourgeois Revolution the human mind was at an early state of its development in which humanity (Humanität) was not yet ready to overcome its limitations, ${ }^{29}$ he was little interested in the specifics of Goethe's use of religion to lend credibility to his humanist vision. By contrast, more than 40 years after Goethe and more than a century before Adorno the Austrian playwright Franz Grillparzer appears to have detected, and parodied, the artful way in which Goethe used the interaction between the Olympian Gods and heroes in Homer's epics as a model for Iphigenie's solution to the conflict within her between religious belief and belief in humanity. This is suggested by a comparison of Goethe's play with a play written by Grillparzer with the same Homeric model in mind as Goethe, but without Goethe's idealistic bias: the comedy (Lustspiel) Weh dem, der lügt! (Woe to him who lies!). In particular, Grillparzer appears to have drawn on the same part of the "Telemachia" that Goethe had used as a model for the renewal of Iphigenie's faith in the Olympian Gods and for her principle of openness and truth. However, Grillparzer's play reveals a very different reading of Athena's advice to Telemachus, one which places it within the context of the Odyssey as a whole and shows Athena as Goddess of Trickery rather than Truth.

Key to seeing the links between Grillparzer's play and Goethe's Iphigenie auf Tauris, on the one hand, and with Homer's Odyssey on the other, is the role of bishop Gregor. The bishop is not only a parody of Goethe himself, ${ }^{30}$ but also recalls Goethe's virgin

Wilhelm Fink, 2003), 41: "Insgesamt finden sich in Goethes 'gräzisierendem Drama' immer wieder Ambivalenzen, Brüche und Inkongruenzen, die ästhetische Vieldeutigkeiten erzeugen und dadurch auffallend modern anmuten."

28 Theodor W. Adorno, Noten zur Literatur, ed. Rolf Tiedemann (Frankfurt am Main: Suhrkamp Taschenbuch Verlag, 1974), 509.

29 Ibid.

30 Just as the bishop is a parody of Goethe, the cooking apprentice Leon is Grillparzer's self parody. See H. Delbrück, "Grillparzers Lustspiel Weh dem, der lügt! und die Iphigenie-Dramen Goethes und des Euripides," Deutsche Vierteljahrsschrift für Literaturwissenschaft und Geistesgeschichte 67 (1993): $140-44$. 
priestess: ${ }^{31}$ in his case, too, celibacy comes with his priestly calling, and like Iphigenie, he firmly believes that no good will come from humanity, unless it is committed to absolute truthfulness: "If only man were truthful, he would be good as well" (line 122). ${ }^{32}$ These are his words in a sermon which, at the beginning of the play, on stage, he prepares for his congregation, starting with a quotation from Jesus' Sermon on the Mount in St Matthew 5:37: "But let your communication be, Yea, yea; Nay, nay." The English translation hides the fact that in this quotation he has Jesus' teaching changed in one important aspect: while Jesus speaks in the plural to the multitudes gathered at the mountain, the bishop prefers to address each and every one as an individual, in the singular: Dein Wort soll aber sein: Ja, ja; Nein, nein (line 118). The bishop also changes the biblical text by turning the command into a prohibition, arguing that lying is the worst of all evils in human nature. However, having written down numerous points to back up this claim in his sermon, he then stops to reflect on his personal reasons for wanting to warn his congregation against lying, and in lines 160-69 he finally reveals that he has changed the wording of the gospel passage to come to terms with the fact that he himself had been lying to the king. At that stage we already know from the bishop's steward that the bishop's nephew Atalus, having been sent to the Rheingau as a hostage to support the peace effort in the war between the Christian Franks and the pagan Merovingians, is kept in servitude by the heathen count Kattwald since the war has resumed. In his own view, had he been "truthful" (line 161), the bishop would have admitted to the king his desire for ransom money to pay off Kattwald, and Atalus would be free. (Obviously, Kattwald in the comedy has the role of Goethe's Thoas.) Thus, by using "your" in the singular (dein) the bishop is addressing not only his audience, but first of all himself, as he is

\footnotetext{
31 The fact that the bishop recalls a man as well as a woman is probably less surprising than the psychological androgyny diagnosed persuasively by Gail Finney (in her article "[En]Gendering the Comic Body: Grillparzer's Weh dem, der lügt!," Modern Austrian Literature 28, numbers 3-4 ([995]:101) in both Leon and Edrita.

${ }^{32}$ While "Thou shalt not lie" is not one of the biblical Ten Commandments, in St John 14:6 Jesus is truth personified: "I am the way, the truth and the life; no man cometh to the father, but by me." In St John 8:44 Jesus calls the devil the father of all lies.
} 
determined never again to be guilty of lying in future. Plagued not only by his bad conscience, but also by heavy heartache for his nephew, he wants to save his congregation from the consequences of lying which he himself is suffering.

Given his strong identification with Atalus who is languishing in servitude, we would almost expect the bishop, like Iphigenie at the beginning of Goethe's drama, to lament:

Woe to him who, removed from parents and siblings,

Leads a lonely life! Grief eats away

His closest bliss in front of his lips [...]. (lines 15-17)

However, the bishop is not a man made for lamenting: ever since his fatal conflict with the king he has been trying to make amends by trying to save money for the ransom himself. This has meant making his cook redundant and eating as little as possible, which of course not only makes him suffer what he believes Atalus is suffering, but is also a vivid demonstration of what, according to Iphigenie's lament, grief does to those who are separated from their parents and siblings. However, according to the bishop's cooking apprentice Leon, who now has to take on all the responsibility for the bishop's bodily wellbeing, all this has been of no avail; the bishop is in danger of starving himself to death, without saving anywhere near enough money to redeem Atalus. Thus, Leon suggests that he might easily liberate Atalus with the help of some trickery (line 328), but is immediately rebuked by the bishop with the stern phrase which in this comedy he will pronounce five times, and which Grillparzer has turned into the title of the play: "Woe to him who lies!" (line 329). In this phrase, the words of Iphigenie's lament ("Woe to him who [...]"), of which we were reminded a little earlier, do in fact resonate, since the bishop's prohibition of lying is perfectly in line with Iphigenie's resolution, in Goethe's play, that her and her brother's Greek humanity must follow without compromise a concept of openness and truth which prohibits the use of any trickery and deceit.

Unlike the bishop and Iphigenie, however, Leon is committed to truthfulness less by natural inclination than by his urge to please 
his master-indeed, he is a compulsive liar. ${ }^{33}$ To find out how serious the bishop is about his prohibition of lies, he asks him whether that rule would apply even if Atalus' life were at stake, and is deeply troubled by the stern response he receives: "Then he may die, and I will die with him" (line 345). The bishop's willingness to take that risk is of course in line with Iphigenie's decision to risk her own as well as Orest's and Pylades' lives by revealing to Thoas their plan to escape. With that risk, taken in act 5 , Iphigenie is close to becoming guilty of the real sacrifice of her brother that in act 3 she had just committed in his imagination, while at Aulis she herself had been the intended victim of the human sacrifice planned by her father Agamemnon. Yet, in the broader context of the curse of the House of Atreus the bishop's willingness to risk the life of his nephew also recalls the original crime of human sacrifice committed by Atreus, who, as part of his rivalry with his brother Thyestes over the kingdom, killed his brother's two sons. But what happens next reveals Grillparzer's lack of empathy for Iphigenie's (in Goethe's play) introspective, soul-searching concept of religion that needs no outward images to support the faith of its followers (a lack of empathy which is not surprising given Grillparzer's origins in Austria's Catholic tradition). ${ }^{34}$ Before committing to truth, Leon needs outwardly visible proof that the bishop's favourite commandment comes from God himself, and the form in which this proof comes shows that Leon is the spiritual son not only of the bishop, but also of Odysseus: the flash in the eyes of the Bishop as he is overcome with religious fervour reminds us of Odyssey 21.414, where Odysseus greets Zeus' thunderbolt from heaven as a welcome "miracle" which forebodes his victory over Penelope's suitors. Without any deep thought, Leon takes the flash in the Bishop's eyes for real lightning, sent by God to confirm the bishop's command that Leon must never lie ("There was a lightning flash,"

33 Ian Roe, "Grillparzer, Weh dem, der lügt!", in Landmarks in German Comedy, ed. Peter Hutchinson (Oxford, Bern, etc.: Peter Lang, 2006), 81: “[Leon's] occasional reticence or caution is a sign of his genuine respect for Gregor [...]"

34 Eda Sagarra, "Grillparzer the Catholic?", The Modern Language Review 97, part 1 (2002): 122: "The primacy of image over abstract idea, characteristic of [Grillparzer's] dramatic oeuvre and often evoked in his own reflections on the theatre, derived from the religious culture which he, as an Austrian Catholic, had perforce inherited." 
line 380), and from that moment (in which the representative of the God of the Christians looks like an embodiment of Zeus), Leon trusts unreservedly in God's intervention to ensure that he will accomplish his mission, provided that he himself does all he can to comply with the bishop's prohibition of any use of lies. At that stage already, his genuine loyalty to God and to his representative, the bishop, indicates that, "ultimately," Leon is "virtuous." 35 When the bishop accepts his offer on condition that on his mission he must refrain from using any deceit, Leon, keen to help, promises to do so.

In this scene, Leon's relationship with his spiritual father, the bishop, also reminds us of book 1 of the Odyssey, as Leon's desire to live up to the bishop's expectations evokes Telemachus' aspiration to grow up and fill the role of his absent father, Odysseus. In order to fulfil his ambition, Leon, too, needs to leave home, and while Telemachus is encouraged to do so by Athena disguised as Mentes, Leon is sent on his mission by the Christian God through his representative, the bishop. Yet the bishop's stipulation would seem to make his mission an impossible task, as Leon remains a notorious liar, and has nothing to support his good will for his mission in the Rheingau except his new-won faith. Therefore it comes as no surprise that, despite the best of intentions, he manages to use apparent openness and truth to camouflage his cheating and artifice: he openly announces to Kattwald that he intends to abduct Atalus, but presents this announcement as if it were a lie. From the start, his urge to lie gets the better of him, and his habitual lying increasingly recalls the crafty Odysseus. This is particularly striking in acts 2 and 4, both inspired by Odysseus' escape from the giant Polyphemus in book 9 of the Odyssey. ${ }^{36}$ Having arrived in the Rheingau, Leon needs to gain access to the house of Kattwald, and the way he obtains it is inspired by the way in which Odysseus manages to win the trust of Polyphemus. While the giant normally only drinks milk from his own goats and sheep, Odysseus persuades him to drink the undiluted wine which he has brought from his ship by making him

\footnotetext{
35 Ibid: 119.

${ }^{36}$ Grillparzer's use of Odysseus as a model for Leon's natural lack of idealism is perfectly consistent with the view among classicists at the end of the 20th century that idealism is foreign to the Odyssey. Cf. Kullmann (n. 21 above), 285: "Jede idealsierende Interpretation muß man von der Odyssee ganz fernhalten."
} 
believe that doing so will allow him to exchange his barbarity for civilisation. Leon uses the same argument to gain employment as Kattwald's cook and, once in this position, he falls back upon it with relish whenever he wants to make the count do what he does not wish to do-including getting drunk. While in act 4 this latter device is part of the plan which Leon designs to escape with Atalus from Kattwald, the end of that act mainly reminds us of that part of book 9 of the Odyssey where Odysseus, without any apparent help from Athena, is left to his own devices of cunning and artifice to escape with his comrades from Polyphemus' cave, whose exit the barbarian giant has blocked with a huge boulder. He decides to use as his key to freedom a wooden stake with which he will blind Polyphemus' watchful eye, after incapacitating him with wine. By contrast, having got Kattwald drunk, Leon sneaks into his bedroom to steal the iron key to the castle from under his nose. (Although that "castle" is primitive and rotten, it is secured by door, lock and key rather than a boulder.) He does not need to blind Kattwald in a literal sense, as he has arranged for the escape to take place in the dead of night, and the count is heavily intoxicated, but Leon finds the actual escape just as difficult as Odysseus after he has blinded Polyphemus. Like Odysseus in the cave of the giant, in the hilarious scene in Kattwald's bedroom Leon needs to employ all the dexterity of word and action that he can muster to obtain his key to freedom.

Nevertheless, at the end of that scene it turns out that Leon's search for the key would have been in vain, had it not been stolen for him by Kattwald's daughter, Edrita. ${ }^{37}$ Only half of Leon's contributions to the purely comedic value of Grillparzer's play come from the ongoing tension between his compulsive lying and his honest attempt to avoid lying at all cost. The other half comes

${ }^{37}$ Egbert Krispyn, "The Fiasco of Weh dem, der lügt," German Life and Letters, vol. 25 (1971-72): 205, highlights the fact that Edrita rather than Leon is responsible for the actual deception of Kattwald: in the scene in Kattwald's bedroom, she also exchanges the key for which Leon is looking by a different key to make him and her father believe that this is the key to the building. While Leon finds it too light to be the genuine article, and says so to Kattwald, he finally believes that he is deceiving himself, as he cannot find any other key: a highly comic case of Leon being at the receiving end of Edrita's trickery. 
from the fact that in the land of the barbarians, unlike Iphigenie, he is not averse to romance at all. However, the relationship between Leon and Edrita is an uneasy one: he cannot accept and declare his love to her, because the principle which she has adopted in helping him to escape is diametrically opposed to the ideals of the bishop. It can be argued that Edrita has been introduced by Grillparzer specifically to target Iphigenie's ideal of humanity based on openness and truth in Goethe's Iphigenie auf Tauris, as espoused by the bishop. One might say that Grillparzer divides Telemachus' protective goddess Athene into two different characters, representing the two sides of the goddess and the two possible choices in Athena's advice to Telemachus that he kill his mother's suitors "either by trickery or openly." While the bishop, in line with Iphigenie's concept of humanity, advises Leon to use truth and openness, Edrita tells him that he and Atalus will never escape from her father without resort to deceit and trickery-and since Leon does not want to go down that path, she herself must use them to help him: at the end of the scene in Kattwald's bedroom it turns out that she has already stolen the key he is still looking for.

When Leon and Atalus have escaped from Kattwald's house, with Edrita joining them of her own accord, the barbarian count summons his people to pursue them. In spite of the fact that the whole play is set in times of war, this is the first time that we actually see the people from the Rheingau engaged in war with the Franks: the small-scale operation that sets out from Kattwald's house in Trier is clearly a comic parody of the Greeks' huge expedition to Troy (to recapture Menelaus' run-away wife Helen) in the Iliad as well as in Euripides' Iphigenia at Aulis, except that Edrita is the fiancée of the primitive barbarian Galomir, a farcical parody of the Greek hero Achilles, with little more than a rudimentary command of the German language: Kattwald's decision to marry his daughter against her will to his friend Galomir matches the way in which Agamemnon, in Euripides, pretends to betroth his daughter Iphigenia to Achilles. The parody is further developed in Kattwald's pursuit of the fugitives: just as Agamemnon in Euripides' play has no qualms about sacrificing his own daughter for the good of the assembled Greek troops, Edrita's father lets himself be carried away to the point of not caring if his men kill Edrita to secure the success of the expedition: 
Fire, keep firing! And were you to hit my child, Much better she be dead - or I should say woundedThan that they escape with her. (act 4, lines 1555-57)

In the fleeting moment of self-correction captured in the parenthesis of these lines, the barbarian Kattwald shows more human feelings towards his daughter than his Greek counterpart Agamemnon in Euripides' Iphigenia at Aulis. However, Kattwald does not intend for his daughther to die, but is merely willing to accept the risk of her death as a side effect of a different action, the recapture of the fugitives. In this respect he invites comparison with Goethe's Iphigenie herself, rather than with Agamemnon: Kattwald shows more human feelings towards his daughter than Goethe's Iphigenie towards her brother Orest and Pylades-and, accordingly, more human feelings than the bishop towards his nephew Atalus when he was too proud to ask the king for a ransom. But at the end of the scene, in comic exaggeration of the aristeia-gestures typical of the heroes in the Iliad before going to battle, Kattwald pronounces his fierce determination "to bathe his hand, his arm, in their [the fugitives'] blood." The fact that Kattwald himself, like the bishop in act 1, will no longer be involved in the operation adds to the comedy of his gesture: he will stay behind on his side of the river, ${ }^{38}$ while Galomir and his troops continue their pursuit of the fugitives.

All this is not known to Leon, who fears for his and his companions' lives. In act 5, finally overtaken by Galomir's troops outside the walls of Metz and believing the city occupied by the barbarians, he is so desperate that, like Goethe's Iphigenie, he asks God for a miracle, indeed demands a miracle, as he feels that God owes it to him to make good his promise (supposedly given in the lightning flash in the bishop's eyes) to save him from the barbarians. The tone of his prayer reminds us of that of Iphigenie's demand that the Olympians should save their image in her soul, and, like Iphigenie's prayer, Leon's must not be accused of being

\footnotetext{
38 The river Rhine as the parting line between nations at war with each other is one of the allusions of the comedy to the Germanic epic, the Nibelungenlied. Another is the sword which Edrita, mockingly, asks Leon to place between them when they sleep next to each other on their flight from Kattwald: a clear reference to the sword which Siegfried places between himself and Brünhild when lying next to her on her second wedding night with Gunther.
} 
blasphemous. ${ }^{39}$ However, when against his expectation Frankish soldiers and the bishop rather than barbarians come walking out of the city, Leon believes that God has in fact answered his prayer by turning the occupying forces of the Rheingau barbarians into troops of the Franks.

At the end of the play, the bishop, Leon and Edrita all reveal their true faces, which are different by more than a shade from the faces shown when they first came on stage. The bishop inadvertently discloses his own lack of trust in the effectiveness of openness and truth when he makes the spontaneous remark that Leon must surely have used deceit and trickery to liberate Atalus from the heathens. Leon's diplomatic response shows that his journey has in fact been an apprenticeship in piety which is now close to completion. He manages to turn the bishop's harsh confrontation into a more pragmatic and, ultimately, more humane maxim in which the two halves of Athena's advice are united in a new coexistence:

Well, admittedly, we weren't perfect.

We took care where we could.

Fully true throughout was only he who helped us: God!

(lines 1720-22)

These words are Leon's journeyman's piece, neither unreservedly criticising the bishop nor siding completely with the cynicism displayed by Edrita in the hunt for the key. But Leon's helper Edrita does not want to be completely entangled in deceit and trickery either. At first she matches his cleverness by telling the bishop that she had only followed Leon "almost against his will" (line 1739), motivated by the desire to become a Christian and a member of the bishop's "pacific congregation" (line 1750). This looks like a new attempt to trick both the bishop and Leon. But Edrita does follow the commandment of openness and truth to the extent of admitting that there had been a second reason for her to follow Leon-one which she will not disclose. Her ability to

${ }^{39}$ Sagarra (n. 34 above): 119, points out that Leon is "far from blasphemy within the Catholic cultural and devotional tradition." 
switch from openness to trickery is exactly consistent with the advice given by Athena to Telemachus in the Odyssey, where the goddess simply does not care whether her protégé uses one or the other, as long as it fulfils its purpose, the revenge on the suitors. This purpose is achieved in the Odyssey when, upon their return to Ithaca, father and son join forces not only in deceiving the suitors, but in drawing them into a gruesome battle in which Odysseus, urged to the attack by Athena and assisted by Telemachus, reveals his identity ${ }^{40}$ and slaughters the suitors.

Of course, the killing of Penelope's suitors is only the immediate purpose of Athena's advice to Telemachus, while its underlying purpose is to save the marriage of Odysseus from being destroyed by the suitors-just as the purpose of the expedition to Troy is finally achieved in the Odyssey, when Telemachus arrives in Sparta and finds Helen of Troy back at home, happily remarried with her husband, Agamemnon's brother Menelaus. This is also Edrita's and Leon's true purpose: in stark contrast to the virgin Iphigenie, they want to be with each other and, ultimately, to get married. For the time being, however, though defeated and captured by the Franks, Kattwald's troops led by Galomir have not disappeared, and the bishop must decide what to do with them. There is no way that in a comedy he would deal with them in the way Odysseus deals with Penelope's suitors, and in contrast to the barbarian Thoas, the bishop needs no persuasion to have the captives set free and to allow them to go home. But this decision lands the bishop and Leon with a problem that Odysseus and Telemachus would have faced, had they decided to set the suitors free in the Odyssey: just as the suitors would not have given up their claim on Penelope, the release of the barbarian captives by the bishop does not solve Edrita's problem with her suitors. While Galomir fortunately soon gives up his claim on Edrita, dragged

\footnotetext{
40 John Davidson, "Euripides and Homer," 20, notes that Odysseus "had gone to consult the oracle at Dodona about how he should return home-ì $\dot{\alpha} \mu \varphi \alpha \delta$ òv $\tilde{\eta} \varepsilon$

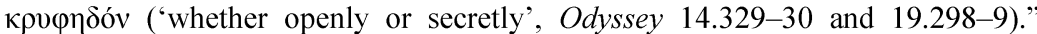
While we do not know the oracle's response, Odysseus chooses to keep his homecoming secret for as long as he sees an advantage in doing so. Telemachus conceals his homecoming by landing his ship away from Ithaca, but no longer sees a reason to do so after he has met with his father and knows that Odysseus himself will take revenge on the suitors. He only discloses his resolution to help his father kill the suitors once his father has begun to kill them.
} 
away by a comrade who convinces him that they need to leave before the bishop regrets his decision, Edrita's second suitor, the spoiled brat, Atalus, presents a more serious problem. ${ }^{41}$ In love with Edrita since his imprisonment in the Rheingau, he asks the bishop to allow him to marry her, and his uncle, impressed by her wish to become a Christian, appears to be willing to give his consent.

Nevertheless, this is the moment when the comedy draws to its happy close. Forced by his competitor Atalus to make a move, Leon finally abandons his belief that the bishop's command that he is not to use deceit and artifice requires him to stay away from Edrita, and he professes his love for her. However, his excuse to Edrita for not having done so sooner is only a half-truth: "He [sc. the bishop] would not have tolerated it. Should I have returned to him with robbery and theft?" (lines 1795-96). The first accusation that he had to face from the bishop upon his return from the Rheingau had indeed been that he had eloped with Edrita, stealing her from her father: "Leon, did you do that to me?" (line 1737). However, the other half of the truth, which he will not reveal, is that he did not want to elope with the girl whom he sees as his perfect match as a liar as well as a lover. After all, he had not wanted her to be involved in the planning and execution of his and Atalus' escape from Kattwald, and he had pulled away from her when he realised, at the end of act 3, that she was helping him by using deceit and artifice. ${ }^{42}$ Therefore his own as well as Edrita's confession of their love to the bishop and to themselves contains half truths which complete the comedy's inversion of Goethe's Iphigenie auf Tauris: while in Goethe's play Orest rescues his sister Iphigenie as an image of Athena the Goddess of Openness and Truth, Leon abducts his lover Edrita as a true image of Athena the Goddess of Openness and Trickery.

Given that Iphigenie auf Tauris is a play about honesty and truth, it is ironic that Grillparzer's Weh dem, der lügt! reveals an

41 Just as some of Penelope's suitors are inhabitants of Ithaca rather than places further afield, Atalus is a Christian from Leon's home town, while Galomir is a barbarian from the Rheingau.

42 In act 5, line 1704, he pulls away from her one last time, complaining that Edrita is "the dark stain in all of this." This line appears inspired by Phaedra's statement to Hippolytus (in Euripides' Hippolytus 317) that she has a "stain in her

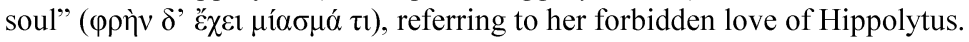


element of trickery, or at least poetic license, in Goethe's use of Homer: its own allusions to Homer show that Goethe's Athena as Goddess of Openness and Truth is a one-sided, idealistic projection of Homer's Athena, the Goddess of Openness and Trickery. However, Grillparzer's comedy is not just about deceit and artifice, but about the ever-present tensions between truth and humanity: an attack on Goethe's exaggeration of an ideal rather than on the ideal itself. Leon and Edrita's final decision to attempt a combination of openness and trickery is far from a guarantee of a happy and "peaceful" marriage, even if their elopement from the barbarian count Kattwald has brought them to the bishop's "pacific congregation." There will always be the issue of what is the most agreeable combination of openness and trickery, and of any other opposites in a marriage: as we know from the fate of Helen in Homer, in the worst case, disagreement in this matter may lead to separation and war.

As truth remains an ideal rather than an attained goal in Grillparzer's play, it is appropriate that bishop Gregor, in his role as Goethe's counterpart, is given the last word. The bishop never denied that he himself does not fully represent the ideal which he preaches: as mentioned earlier, at the beginning of the play he chides himself for the pride which made him conceal from the king his wish to have Atalus redeemed from the Merovingians. Now, at the end of the play, he is willing to swallow his pride and ask the king to consent to his decision to adopt Leon as his second nephew, which will make it possible for the cooking apprentice to marry the daughter of a Count (lines 1811-13). Thus, Leon's and Edrita's marriage will overcome the boundaries between civilised Franks and barbarian Merovingians, between heathens and Christians, and between high and low ranks in society. Moreover, the bishop's assent to it demonstrates some insight into the fact that his own obsession with truth has in fact been a red herring that cannot be relied upon to save humanity: indeed, it had had the potential of turning humanity, once again, into its barbaric opposite, like any other principles pursued to excess, including the political goals pursued by Agamemnon at Aulis or, closer to home, the pride that had driven Atreus' fight with his brother Thyestes. By asking Leon to rescue Atalus from the barbarians without any use of lying, the bishop had risked the lives of both Atalus and Leon: his decision now to adopt Leon as his second nephew completes the comic reversal of his role as Iphigenie's forefather 
Atreus who in his power game with Thyestes had sacrificed two nephews.

Perfectly happy with his own progress towards Christian humanity, the bishop begins his concluding speech by consoling Atalus with a conciliatory homily on the kingdom of God, in which, according to the bishop, lies are God's own way of saving human eyes from the blinding light of the eternal truth that is reserved to God alone, and he advises Atalus to devote himself to the study of theology (lines 1821-23, cf. line 905). But then he abruptly ends the play, turning to the two difficult lovers:

And those over there

[Turning around with a movement of his upturned hand:]

May they get along.

In these lines, the self-assured flow of the bishop's words is interrupted by an incomplete sentence which reminds us of the two one-syllable words ("Her there," Die dort!, line 1732) with which the almost dumbstruck Galomir had pointed at Edrita to claim his right to her. In front of God and the audience, with a mixture of benevolence and self-righteousness, Gregor gives his blessing to the couple's marriage and thereby reclaims his pastoral right to admonish them as members of his flock. But as he has finally realised that his ideal of a life without lying would be lost on them, he mildly recommends, rather than commands, that in their marriage they should keep the peace: a task which, from the evidence the bishop has seen since his arrival in Châlons, will be no less challenging for them than a life without lies. ${ }^{43}$ But the bishop's change of tone signals more than simply the softening of a prohibition into an admonition, since it also evokes Thoas' final blessing to Iphigenie and her brother: "Fare well!" This metamorphosis of the bishop, so to speak, from Goethe's protagonist Iphigenie to Thoas, brings home to the audience the main point of Grillparzer's parody of Goethe's Iphigenie auf

43 Cf. William C. Reeve, “Weh dem, der lügt!: Grillparzer's Janus-Faced Comedy," The German Quarterly 77, no. 1 (2004): 73: “The concluding comment and gesture put the happy ending in doubt by intimating how fragile happiness can be for those who pursue it in the deceptive transitoriness of earthly existence, arguably the same pessimistic message at the heart of all of Grillparzer's tragedies." 
Tauris: that it is the humanist teacher Iphigenie herself who would have benefited from a lesson in the limitations of humanity.

By extension, Grillparzer's criticism of Iphigenie is directed against her creator, Goethe. But in playing off Homer against Goethe, his comedy is far from radical or ruthless. The humanity in the words of wisdom which we have called Leon's journeyman's piece is much closer to the spirit of Goethe's play than to the callousness with which Athena opens the road to both openness and trickery in her advice to Telemachus. And the bishop's mellowing-down, which has brought him as much closer to Leon's philosophy of life as Leon has come closer to that of the bishop, shows Grillparzer's appreciation of the uneasy balance in Goethe's play between the progress of humanity and the ever present danger of its collapse to tragedy. ${ }^{44}$

44 Maria Dorninger, "Der Küchenjunge Leon: eine Gestalt Franz Grillparzers in ihrem figuralen Umfeld," in Die lustige Person auf der Bühne: Gesammelte Vorträge des Salzburger Symposions 1993, ed. Peter Csobádi et al. (Anif/Salzburg: Verlag Müller-Speiser, 1994), 626, notes that Grillparzer's concept of comedy (Lustspiel) was that of the French comédie, comprising any play without a harsh ending ("ohne herben Ausgang"). However, on p. 624 she also notes that in the early stages of his work on his comedy Grillparzer used to include the title Weh dem, der lügt! in his list of topics for tragedy. Obviously, unlike the French comédie, as a final product Grillparzer's Weh dem, der lügt! still features that vital link to tragedy which Goethe's drama Iphigenie auf Tauris had inherited from Euripides" "tragedy without a tragic end," Iphigenia in Tauris. 